\title{
A STUDENT-CENTERED EDUCATIONAL APPROACH SCIENTIFIC REASONING AND EMPIRICAL STUDY AT THE UKRAINIAN UNIVERSITIES
}

\section{Olena Stoliarenko ${ }^{1}$ \\ Oksana Stoliarenko}

DOI: https://doi.org/10.30525/978-9934-588-15-0-19

\begin{abstract}
The present paper covers the student-centered educational approach principles and presents an empirical study held for student teachers at Vinnytsia State Pedagogic University, aiming to promote teaching and learning processes based on a student-centered approach. The article suggests the main principles of student-centered educational approaches which imply the fact of students and teachers relationship being grounded in mutual respect and reflexion about teaching and learning process. University teachers focus on students' learning and seek for active and deep learning, and, therefore, students' responsibility, accountability and autonomy. Student-centered approaches stimulate study, thinking and practice abilities because instead of being passive in the classroom, imitating teachers' explanations and demonstrations, they are active in the learning process, developing independent thinking and self-regulated study. Self- and co-regulation skills are really important for students to be able to manage their time and effort focused on studies, thus increasing involvement. Universities should promote learning environments where students are active in their learning processes, producing their own knowledge instead of just repeating what teachers say. The findings of this study identify that the student-centered approach to teaching encourages students ${ }^{\text {ee }}$ engagement in teaching-learning activities focusing on individual interaction to achieve common objectives. However, inadequate resources, lack of expertise on the part of teachers were the challenges to the teaching learning activities.
\end{abstract}

\footnotetext{
${ }^{1}$ Doctor of Pedagogic Sciences,

Associate Professor at Department of Pedagogics and Professional Education,

Vinnytsia State Pedagogic University named after M. Kotsiubynskyi, Ukraine

${ }^{2}$ Candidate of Pedagogic Sciences,

Associate Professor at Foreign Languages Department,

Vinnytsia National Technical University, Ukraine
} 
A student-centered educational process study was set up as a pedagogical research. The classes were initially planned based on interviews with teachers and students from the regular previous term and on open-answers questionnaires filled in by the students. At the end of the action research a new open-answer questionnaire was filled in by the students. The investigation showed and proved positive changes on students' postures, engagement and learning. The findings indicated that student-centered practices were an interesting pedagogical approach for future teachers. Besides going further with the pedagogical research it is perceived the need to make similar studies at different Ukrainian Higher Educational establishments.

\section{Introduction}

This paper presents an empirical study held at Vinnytsia State Pedagogic University for student teachers, aiming to promote teaching and learning processes based on a student-centered approach.

Ukrainian University teachers are expected to report annually their teaching activities and outcomes. Recent survey results have shown that student teachers have low level of pedagogical skills. Besides the items about teachers' ability to promote students' interest about subjects of study and use of a teaching strategy that facilitates learning received the lowest scores from students in the past five years. When the students are asked about their self-evaluation, most of them consider themselves surface learners. Regarding this last data it can be concluded that students are aware of the necessity of being more proactive about their learning. Some educators highlight that students persistently complain about outdated and low flexibility curricula, old-fashioned pedagogical approaches and a poor connection between theory and practice, relating these issues to students drop outs.

The main trends of youth's moral education in this sphere were founded by the classics of pedagogy J. Dewey, Ya. Komenskyi, Ya. Korchak, K. Lewin, A. Makarenko, M. Montessory, J. Piaget, K. Platonov, S. Rubinshtein, V. Sukhomlynskyi, K. Ushynskyi, S. Phrene, R. Shtainer). Today universities are concerned about university teachers thinking and pedagogical skills, and, therefore, are researching and offering training in order to improve them (I. Bekh, A. Bixley, O. Asmolov, P. Blumberg, S. Bondyreva, N. Entwistle, M. Lipman, D. Kolesov, O. Kleptsova, O. Kononko, V. Maralov, F. McDonald, J. Reynolds, K. Rodzhers, V. Sitarov, U. Solda- 
tova, O. Stoliarenko and others). For the past decades, different innovative teaching approaches and techniques are being developed and implemented in Ukrainian universities. They deal with technology use, problem-based learning or gamifying education.

Ukrainian educational challenges go from low achievement, lack of interest for learning, school drop outs to the need of enhancing teachers' quality and reduce teachers drop outs that could benefit from educational courses with student-centered approaches.

In the research focusing on university teachers' concepts of teaching and approaches to teaching, the two diverse approaches to teaching have been identified: content-centered and teacher-focused versus learning-centered and student-focused. In the content-centered and teacher-focused approach to teaching, university teachers perceive teaching as more traditional lecturing, and the main focus is on the teacher and his/her role transmitting knowledge. In the latter, learning-centered and student-centered approach to teaching, university teachers focus on students' learning and seek for active and deep learning, and, therefore, student's responsibility, accountability and autonomy. In the student-centered approaches, the relationship between students and teachers is grounded in mutual respect and reflexion about teaching and learning process [22, p. 326].

The use of teaching methods based on student-centered approaches at higher educational establishments has been broadly discussed and practiced in institutions both in Ukraine and all over the world. There are several pedagogical practices that can be called student-centered, at this article the focus is on pursuing students' interest, motivation, deep learning and autonomy. The idea that a student will learn better when interested in the topic of study is a widespread idea, if a teacher seeks for students' interest, instead of having a strictly disciplinary structure of contents, s/he should plan the classes based on the student interests. In that case, it is not the student who should get interested in the topic, the topic needs to be dealt in an interesting way for the student. It is important to note that teachers' student-centered approach won't necessarily promote deep approaches in learning [17, p. 118]. N. Entwistle defines deep approaches in learning as processes that "can lead to tight, integrated forms of understanding and to an awareness of their understanding as a knowledge object" [8, p. 30]. The authors continue stating 
that courses can encourage deep approaches in learning by making clear, since the beginning, what is expected from them both in thinking and practice. The teacher must use lively and clear explanations and adequate language. Moreover, it is important to exemplify ways of thinking and practicing, to give the possibility of choosing assignments, work with real problems and to be alert to notice and deal with possible difficulties that may appear. F. McDonald, J. Reynolds, A. Bixley, R. Spronken-Smith in their scientific article suggest 6 principles to encourage deep approaches in learning: 1) alignment of course outcomes with taught material and with assessment model; 2) transformative learning experiences such as the opportunity to develop practical skills; 3) discussion of lecture and laboratory material with peers and lecturers; 4) assessment that encourages a deeper approach in learning; 5) considering the student workload and 6) regular teaching workshops [12]. A common critique made about the university is that many graduates find difficulties in solving complex real-life problems by using their academical knowledge. That situation is difficult to solve with traditional teaching approaches, according to I. Bekh. The author advocates that student-centred approaches stimulate study, thinking and practice abilities because instead of being passive in the classroom, imitating teachers' explanations and demonstrations, they are active in the learning process, developing independent thinking and self-regulated study. Self- and co-regulation skills are really important for students to be able to manage their time and effort focused on studies, thus increasing involvement and decreasing drop-outs. Actions that can help the development of self- and co-regulation skills include collaborative learning and self- and peer-assessment [1]. Regarding assessments, O. Stoliarenko cites a pedagogical student-centered experience where open-ended group activities promoted more students participation on discussion about real-life situations. Due to the fact that grades were given upon participation, students felt stimulated to share their thoughts, not worrying about being right or wrong. This posture made possible for students to practice [3].

Universities should promote learning environments where students are active in their learning processes, producing their own knowledge instead of just repeating what teachers say. According to the authors, in order to achieve this goal, the teachers' actions and postures are to be fundamental [2; 4]. 


\section{Student centered approach to teaching: theoretical basis}

A student centered approach to teaching is conceived as an instructional philosophy and modern pedagogical approach, which is opposite to teacher centered approach, i.e. the conventional teaching methodology in which the teacher remains at the centre of instruction in the teaching learning process. J. Dewey asserts that traditional way of teaching has the limitation to focus on active learning and explains that «...there is no defect in traditional education greater than its failure to secure the active co-operation of the pupil in construction of the purposes involved in his studying» [6, p. 67]. However, teaching focused theories like Bloom's Taxonomy, experiential learning of Kolb based on J. Dewey's, K. Lewin's and J. Piaget's concepts of learning and flexible approach to teaching revealed that student centered approach to teaching is a paradigm shift from teacher to learner-centered, a deliberative effort to facilitate learner to achieve learning objectives by creating conducive learning environment using a variety of activities like activity based teaching with effective interactive relations between learners and teachers [10]. In light of the perceptions of quality education, it is like ,one size does not fit all ${ }^{\text {le }}$ paradigm because of its transition and dynamic nature. Its definition changes from person to person, community to community and country to country from time to time and who defines it under specific circumstances depending upon the influence of cultural, historical, local, national, international and global perspectives. However, the concepts of quality education to the community are: 1) children are given access to modern facilities like computer education according to their grade level; 2) individual attention is given to overcome learning difficulties through learner focused teaching; 3 ) teachers are given opportunities to learn through training, workshops, seminars, co-teaching with expert teachers to improve teaching learning practices; 4) providing students with opportunities to participate in local, regional and national level competitions to show their talents; 5) monitoring and evaluation of every teaching and learning activity is ensured through internal and external institutional support; 6) learning achievements are shared with parents, community and supporting institutions to encourage children to excel in curricular and co-curricular activities; 7) high achievers, competition winners and runners-up are appreciated in the community programs to boost their morale; 8) every event or activity 
is organized around learners' development and is well justified [5]. These perceptions of the school stakeholders are considered as quality standards.

In the light of Weimer's Model of learner centered teaching, the quality standards in the educational establishments are evaluated through the exploration of perceptions, beliefs and practices of the teachers and students. According to this model, the five key premises are: 1) power shifts from teacher to a more egalitarian classroom - from teacher centered to student centered; 2) the use of content is just for students to think critically; 3) a shift in authoritarian role of teacher to facilitator; 4) return the responsibility for learning to the students; and 5) utilize assessment measures not just to assign grades, but to promote learning The first key component of Weimer's Model, a paradigm shift from teacher centered to student centered, is the main indicator that teachers are using student-centered approaches [24]. In this approach, the role of teacher remains a helper, facilitator, mentor, „formator" and a guide whereas students" role remains central in the whole process as "active participants in learning and co-constructors of knowledge" [13, p. 111]. This active participation of students creates enjoyment in their learning through exploration and construction of knowledge where the teacher encourages, mentors and engages them in critical thinking process to achieve the desired objectives of learning. As a result of this relationship, an egalitarian classroom environment is created in such kind of practices. In this whole process of teaching and learning, if a child does not come up to the mark or to the set standard "the child is not dismissed as a failure; rather the teacher considers what can be done to enable this child to learn» [11, p. 226] and this concept is somehow linked to the perceptions of providing quality education at the community schools. However, Simon argues that focusing every individual in such a way is not possible in practice. For example, in a limited time period if teachers will give more focus on slow learners that may result in ignoring fast learners. However, it is very difficult to experience such kind of power shift in cases of more experienced and senior teachers and it is also very difficult to say such practices necessarily reflect the essence of quality education if individuals are treated in such a way. So, it may be quality education for children with learning difficulties but it may only be the loss of time for others in the same class. It is widely agreed that teaching is not something depositing into the minds of learners through teachers"e control rather it is creating opportunities to 
individual learners to overcome learning difficulties by involving in learning situations with mainstream learners where they can come with their own creativity through exploration and interaction [20, p. 40]. In this connection, a student centered approach is an interactive way to facilitate learners who have different ideas and views to share with each other in smaller group settings to get insights of a topic under discussion. However, involving children with empowerment in their preferred activities can reinforce their participation in all activities because students are not motivated to learning every time. On the contrary, it is the teacher who creates conducive learning environment by selecting such preferred learning activities which can reinforce children to show their interests in the class. In doing so, teachers have to interact friendly focusing on task to facilitate learning with appreciation for active participation to boost students' interest towards learning; and such kind of friendly interactive facilitation is considered as a way to provide quality education in different educational establishments [4, p. 39]. According to J. Guthrie, to create interest in learning, teachers use multiple ways to engage learners through a variety of activities like activity based teaching. Thus, the concept of student-centered approaches is to focus on activity based teaching with a clear focus on improving the learning conditions of students who can take responsibility for their learning by working together in a group. Creating conditions for students to take part in activities with self responsibility develops confidence and improves achievement in their life chances. However, there does not exist a clear evidence to support the direct relationship between activity based teaching and development of self responsibility in learners [9, p. 13]. Moreover, a student-centered approach is a paradigm shift in teaching methodologies in order to create a cooperative and collaborative learning environment in their classroom. One of the aims of paradigm shift was to minimize negative competition focusing more on getting high grades rather than on active learning. Theoretically, the rationale for paradigm shift was to make students realize the value of success in group work by achieving common objectives rather than being in a race of competition among their classmates. Contrary to this, the concept of quality education in the educational establishments focuses on competitions and race among students to be the first among others. Therefore, it might be quality education for this school system but not for others. Moreover, a student-centered approach in light of this model is a coopera- 
tive learning environment where teachers use the content as a source to help learners build on their prior knowledge to connect their ideas and discuss things in group, providing equal chances to express, apply to their context, analyze the situation, and create conceptual understanding of a topic under discussion. It helps students to learn by communicating their understanding, experiences and helping their peers to convince their views where teachers become co-learners in these interactive discussions with different talents, abilities, and background of learners to [15, p. 20]. However, it is not so simple for every novice teacher or even for some experienced teachers who have the fear of loss of power of authority or may not have the motivation to change their classroom as a platform for socialization for purposeful learning. All the five key premises of Weimer's model in light of quality education as defined by the educational establishments can be reflected in the forms of «self regulated learning practices where students' motivation, confidence and interest for learning are all adversely affected when teacher controls the process through and by which they learn» [24, p. 23]. In such a situation where the teacher controls the whole process of teaching and learning, almost all decisions are taken by the teacher for learners. In addition to that, the content focused practice for any justification, i.e. to complete the syllabus, is also another indicator to teacher centered approach. Whereas in a student-centered approach, a conducive learning climate is created and students are given multiple opportunities to take most of the decisions related to their learning and interest. An environment of trust and respect for each other, collegiality and cooperation for team learning and demonstration of high confidence and freedom for learning with ,,autonomy and responsibility ${ }^{\text {ee }}$ is practiced in a student-centered approach classes [24, p. 102]. In such a situation, students can seek support, guidance and feedback whenever required and the role of the teacher remains a friendly facilitator, not a decision maker. This key concept of the model is used to evaluate the student centered approach to teaching through an exploration of teaching learning practices in the context of this study.

\section{Research methods}

This study aimed to answer three questions i.e. how students and teachers perceive the importance of teacher training; what kind of experiences student teachers have at a course based on traditional teaching methods; 
what kind of experiences student teachers have at a course based on student-centered approaches.

The study is a case study and applies action research approach, more specifically a pedagogical action research approach, which is defined by Norton as a procedure for teachers to investigate and reflect about her/ his own teaching/learning facilitation practice and improve it. The author designed the case study to follow five steps of an action research:

Step 1: Identifying a problem.

Step 2: Thinking of ways to solve the problem.

Step 3: Doing it.

Step 4: Evaluating it (actual research findings).

Step 5: Modifying future practice [14, p. 70].

For the purpose of this study, the first two steps were conducted in two phases, labeled Study A and Study B. Study A was exploratory study and Study B, after a previous exploratory part, was put into practice.

\section{The course of the investigation}

The study was conducted at Vinnytsia State Pedagogic University, a public state institution, regarding the undergraduate course "Educational Training Methodology" from the Teacher Education curriculum. All the students were from careers that lead to school teaching, such as Geography, English and Maths. The teachers were doctoral students and professors from the Department of Pedagogics and Professional Education.

Study A consisted on interviews with four teachers who taught "Educational Training Methodology" course with traditional teacher-centered approaches ( 2 professors and 2 doctoral students) and 12 students who were taking the course with these teachers. Study B was held on a "Educational Training Methodology" course, but that was offered as a practical extracurricular course, with the same amount of credits and was based on a student-centered approach. The classes were conducted every morning, from Monday to Friday, for three hours, during 15 days. After that period, the students had 10 days to elaborate the assessments, with e-mail feedbacks whenever it was requested. At the first class of Study B, students talked about what they would like to learn at the course and answered open-ended questionnaires about themselves as students and opinions and suggestions to make classes better. Students were told that the course would be part 
of an action research and that their suggestions would help planning the classes. At the second day, the teacher presented the teaching plan, designed from the students interests and suggestions and also based on the items of the L, Trigwell and M. Posser's approaches to innovative methods of teaching - Conceptual Change/Student Focused part, principles to encourage deep approaches in learning. The assessment plan was decided collectively and comprised creating a teaching plan regarding their fields of study and self-evaluation with daily reflections $[19$, p. 31]. The classes consisted of four sessions (Table 1).

Table 1

Classroom activities at the student-centered course

\begin{tabular}{|c|c|c|c|}
\hline Session & Quantity & Topics & Activities \\
\hline 1 & $\begin{array}{l}\text { Six } \\
\text { classes }\end{array}$ & $\begin{array}{l}5 \text { main authors and } \\
\text { review }\end{array}$ & $\begin{array}{l}\text { Theoretical explanations and group } \\
\text { discussions }\end{array}$ \\
\hline 2 & $\begin{array}{l}\text { Four } \\
\text { classes }\end{array}$ & $\begin{array}{l}\text { Theory applied to } \\
\text { students' field of } \\
\text { study }\end{array}$ & $\begin{array}{l}\text { Two classes with theoretical discussions } \\
\text { and group work planning practical class } \\
\text { activities } \\
\text { Two classes with class activities practical } \\
\text { experiences }\end{array}$ \\
\hline 3 & $\begin{array}{l}\text { Three } \\
\text { classes }\end{array}$ & $\begin{array}{l}\text { Psychological } \\
\text { topics }\end{array}$ & $\begin{array}{l}\text { Small and big group discussion, } \\
\text { Questions and Answers session, group } \\
\text { work planning practical class activities. }\end{array}$ \\
\hline 4 & $\begin{array}{l}\text { Two } \\
\text { classes }\end{array}$ & $\begin{array}{l}\text { Teacher-student } \\
\text { relationship } \\
\text { Review and closure }\end{array}$ & $\begin{array}{l}\text { A talk with a teacher from the University, } \\
\text { responsible for engineering courses with } \\
\text { small failure rate }\end{array}$ \\
\hline
\end{tabular}

At Study A, the interviewed teachers were from Vinnytsia State Pedagogic University and the students were from different careers focused on teaching who were enrolled at "Educational Training Methodology" courses given by those teachers. Research assistants contacted all the 6 teachers responsible for the discipline and four of them wanted to participate. After that, research assistants present themselves at classes from these teachers looking for volunteered students. Twelve students manifest interest in participating in the research and gave their telephone numbers to be contacted later.

At Study B, the teacher was a Doctor of Pedagogics from Vinnytsia State Pedagogic University. The students were from different careers focused on teaching who were enrolled at "Educational Training Method- 
ology" courses offered at the extracurricular time, with the same credits as the regular course. At the first class it was explained the purpose of the class and research and all the students agreed on participating. At the beginning of the course, 34 students answered the questionnaires. At the end of the course, this number dropped down to 27 students.

Study A consisted on semi-structured interviews, because it was a smallscale research where the main focus was on the quality of information that could be obtained by a focused conversational two-way communication, which is supported by $[7 ; 16]$. The topics covered on the interviews were related to opinions about the discipline, teachers and students postures, and suggestions to make the course "Educational Training Methodology" better.

At Study B, the number of participants was higher and, specially, there was not much time available since the main purpose was to put into practice the suggestions made in both studies. Another important aspect was to assure the students full anonymity to express their opinions, to pursue a not biased data: neither too positive looking for good grades, nor silencing possible criticisms. The chosen instruments were open-end questionnaires, answered twice, at the beginning and at the end of the course, with the following questions:

The first-day questionnaire was exploratory and comprised the following questions:

- What were the reasons for your career choice?

- Is this your first undergraduate course? If not, what was the career?

- Would you like to change your career? If so, why?

- What is your opinion about becoming a teacher?

- What is your opinion about the Teacher Education courses?

- What are your expectations (including the negatives) about this course?

- How do you see yourself as a student?

- How do you learn?

- What teachers could do to make classes better?

- The last questionnaire had the following questions:

- How did you see yourself as a student in this course?

- How did you learn in this course?

- What were the positive and negative highlights of the pedagogical practices of the course?

- What is your opinion about the course? 
- Were your expectations met? Which ones?

- Do you want to become a teacher?

- If you were the teacher of this course, what would you do differently?

E. Singer and M. Couper claim that open-ended questions are important because they increase participants' sense of engagement and also provide more detailed data. In the particular case of the study, we aimed to provide not only sense, but real students' engagement and participation at the course, since its elaboration and execution. It is important to note that some numbers will extrapolate the number of participants, this happened because students from Study B often gave complete answers, providing plenty information [21].

\section{Findings of the investigation}

The research had a qualitative approach and used thematic analysis for the final questionnaires analysis. Thematic Analysis is seen as a good option when working with learning and teaching processes because the diversity education has in it benefits from a more flexible method, not tied to a particular perspective. At the exploratory study, made with the interviews and a questionnaire at the beginning of Study B, the suggestions, critiques, interests and approaches to study were categorized to identify issues and to plan an approach to deal with them at Study B classes.

All teachers perceive that undergraduate student teachers do not understand the importance of the "Educational Training Methodology" course and are enrolled at the course just because it is mandatory. As for Study A students' opinions about their own posture at the course it can be concluded that nine students considered the courses neither important nor interesting and they were not aware in them, but for three students they were rather interesting. Answering the question what could be improved in classes nine students wanted to be more participative; six needed better teacher's didactics and four did not know how to answer.

Students from Study B prior to classes saw themselves mostly as interested and dedicated students (nineteen); five acknowledged that they could be more dedicated students; three described themselves as lazy and relapsed students and added that wanted to change this situation. One student qualified herself as a terrible student, another one as a regular and the last one as a frustrated student. Four did not answer. When asked about the reasons for 
choosing a teaching career, Study A answers were more related to employment ( 7 of 12 students). All students gave also other explanations, each one with four mentions: had inspiring school teachers, willing to "make the difference" and relating the choice as an innate condition. At Study B, most parts of the students ( 29 of 34) explained to have chosen their career because are interested about the subject. The expressions "love" and "passion" were used 6 times to express this interest. Only two related the choice to employment, one wanted to "make a difference", one did not answer and one said that it was because of lack of options.

Students from Study B perceive their future as teachers, both prior "Educational Training Methodology" extracurricular course classes and afterwards. Although seven students did not reply to the second questionnaire. But the general tendency of students' willingness to become teachers tends to be positive.

As for students' from Study B experiences of learning in student-centered course, that is when they were asked about how they learn, 24 of the 34 students listed individual methods such as reading and watching videos. More than one manner was appointed by most part of students. The other methods mentioned were practical activities and dynamic classes (11 students); classes explanations (9 students); debates (3 students); examples (3 students); teaching (1 student).

Regarding their expectations at the beginning of the course, 24 students wished it helped them being good teachers. 2 students missed the first class, answered the questionnaire on arrival and reported that after attending the first class, have come to have good expectations. Students' expectations for learning in the student-centered course ranged from their will to experience some good course ( 6 students) to the lack of interest ( 2 students). 2 persons expected to become better students, 2 students wanted just to be approved.

Students opinions about teacher education courses were mainly positive, but with some variants. 13 students considered them to be very important and necessary; 5 did not like humanities courses; 3 complained at previous bad experiences and for 3 students it was their first experience and they had no opinion formed.

The content analysis of the open-end answers on the students' experiences of learning in Course B questions was divided into five categories: 1) students stating that prior to the course they did not want or did not con- 
sider becoming school teachers and, after classes, are willing/thinking more often about to pursue this professional path; 2) students reporting a growth at their dedication and effort to study; 3 ) significant learning to become a good teacher and proper learning; 4) opinions about classes being good and motivational; 5) surprised with teaching practices and their own postures as students. There was a student whose questionnaire did not contain any of the themes listed and neither brought other shared topics. It showed insatisfaction with the pedagogical approaches, pointing out that she learned only by her reading at home and did not feel interested in classes.

Students of the both courses (traditional and student-centered) emphasized in their answers the importance of active learning to improve their engagement and learning in teacher education. The analysis of students' suggestions to improve the classes showed that the majority of them were interested in interaction, participation, practical and contextualized activities (29 students), 7 students needed dialogue and more respect between teachers and students, 5 considered it necessary to deepen the theory and objectivity at the classes was important for 3 students.

\section{Reflexion and discussion}

Students from Study A seemed to be less motivated, had fewer opinions (the answer "I don't know" was said repeatedly). Moreover, their self-perception as students were not good and they were mainly not interested in the "Educational Training Methodology" course. Students from Study B seemed to be more motivated, with a better self-perception as students and affirming to be more interested in the course. One possibility for this to happen is because students start a course interested in it, but as the classes go by, they lose their interest. At the same time, there is an expectation that courses (in general or from the Teacher Education curriculum specifically) will be unpleasant, even if it is not verbalized. Most parts of students from Study B expressed an expectation for the course to be useful and, at the end of it, some admitted that the first expectation, before classes started, was negative. Maybe, because they perceived themselves as being part of the course construction, with a teacher being interested at their opinions and suggestions, they felt more motivated to contribute and experience the classes [21].

When explaining the reasons for the chosen career, the high possibility of employment was often stated in Study A, while at Study B the reasons 
for the chosen career were related to intrinsic motives. The need for an employment assurance is a good reason to not quit studies. Considering the big rates of drop outs among student teachers in Ukraine and the fact that the University related it to outdated and low flexibility curricula, old-fashioned pedagogical approaches and a poor connection between theory and practice, if a student is not satisfied with pedagogical approaches at University, the need of a diploma to pursue employment is what keeps the student somehow motivated, rather than personal reasons. Because students from Study B felt more engaged in the course construction, there was no need for an external reason to believe in the importance of the chosen career for their future. For the specific course of Study B research, all the suggestions were put into practice, as well as students' difficulties, criticisms and obstacles were taken into consideration. That is the initial understanding of student-centered this study has: students are the center of the learning processes and classes have to be a collective construction. At Study B all students' suggestions were pedagogical practices understood as student-centered or deep learning encouragement: active students; relationship respect between teacher and students and work with real problems.

One concern of this pedagogical research was to encourage deep approaches in learning, from the 6 principles suggested by F. McDonald, J. Reynolds, A. Bixley, R. Spronken-Smith only one item, regular teaching workshops, was not possible to fulfill [12, p. 72]. Also, L. Postareff's reflexions about student-focused approach were part of the everyday pedagogical planning and practices [18]. From the themes that emerged from the second questionnaire of Study B it was possible to see that student teachers not only had good experiences at a course based on student-centered approach but also that it was seen as useful for future professional practices, even helping supporting the career decision. The course also was seen as important for the development of studying practices. About the will to become a teacher, at the first questionnaire 2 students have not decided; other 2 answered that it was unlikely; 1 replied negatively and 1 did not answer. At the last questionnaire, only 2 answered negatively and 4 affirmed to be considering it as a possibility. More specifically, at four questionnaires highlighted the idea of changing opinion towards being a teacher because of good experiences at the course. Having a positive experience as a student can motivate the aspiration of being 
a good teacher, the fact that can help decreasing drop outs at Teacher Education careers. This contributed to the fact previously discussed about reasons for career choice indicates that feeling and being part of a course is important for student teachers' professional future. Sixteen students reported a growth on dedication and effort on studies because of the pedagogical approach used at the course. It included a raise of awareness of the challenges they face as students and the need to find out ways to learn more and better. These are self-regulation skills, important to increase involvement and decrease drop-outs and to stimulate study, thinking and practice abilities. Thus, the practice reduced the lack of students' commitment with classes that appeared as teachers' complaints and students' self-criticism on Study A. Additionally, students learn how to study and learn in different ways than by individually, as it was reported at the first questionnaire. The recurrent theme (mentioned by 21 students) good and motivational classes showed that student-centered pedagogical approaches promote students' interests about subjects of study and that the teaching strategies used facilitated learning, the items that had lowest scores at the last five annual reports of the University where this study took place. It is interesting to note that more than half of students were surprised with the course teaching practices and their own involvement with it, showing that university students are not expecting classes to be good or that they will be interested and engaged at studies. University can be more than a path to a curriculum; it can be a place to learn, practice, reflect, being active at knowledge production and to develop as a whole human being. Significant learning was a theme expressed by 16 students, regarding two specific skills: useful knowledge for professional life and proper learning of the course subjects. The student who was enrolled at the course for the third time said that could learn better at the course. Although the majority of students can be average students, there are some who need a different approach to be able to get interested, motivated and learn. More than that, this knowledge has to be applied on their future occupation, which was one of the major expectations students expressed on the first questionnaire: 24 students hoped the course would help them being good teachers. Theory is often disconnected from practice, making more difficult for students to engage at deep learning approaches to study, leading to a possible professional with surface knowledge and practice. 


\section{Conclusions}

Teaching methods based on student-centered approaches showed to be interesting practices to cope with the high rate of complaints about teaching methods at the Vinnytsia State Pedagogic University annual report, the urge to decrease student teachers drop outs and to increase the quality of the future school teachers. We propose a teacher education that not only reproduces knowledge and pedagogical practices but also encourages student-teachers to produce knowledge and to think and propose strategies to reconfigure the format and dynamics of the classes, with greater student participation. This type of educational practice makes teachers and students aware of their importance and responsibility in the teaching-learning process. Writing a learning journal, evaluating yourself and the teacher procedurally, and building the course plan collectively are all part of the awareness-raising process that enhances student-centered teaching.

The experiences reported by student teachers at the course were important to support the course's student-centered approach and also gave important feed-backs to go further with this educational research, next time at a regular course. It is suggested to carry out more studies with student-centered approaches at Vinnytsia State Pedagogic University, beyond teacher education.

\section{References:}

1. Bekh, I. (2008). Human Personality Forming. Kyiv: Libid.

2. Bekh, I. (2009). Psychological Aspects of Training. Kyiv: Akademvidav.

3. Stoliarenko, O., Stoliarenko, O. (2014). Teaching the Culture of Tolerant Relationships to Students. Vinnytsia: Nilan-LTD.

4. Stoliarenko, O., Stoliarenko O. (2018). Valuable Attitude to a Person in the Theory and Practice of Education. Scientific Notes of Vinnitsa State Pedagogical University named after Mikhail Kotsyubynsky. Series Pedagogy and Psychology, $55,38-42$.

5. Blumberg, P. Implementing Learning Centered Approach in your Teaching. Philadelphia: University of the Sciences in Philadelphia.

6. Dewey, J. (1938). Experience and Education. New York, NY: Macmillan.

7. Drever, E. (1995). Using Semi-Structured Interviews in Small-Scale Research. A Teacher's Guide. Edinburgh: Scottish Council for Research in Education.

8. Entwistle, N., Hughes, J., \& Mighty, J. (2010). Taking Stock: An Overview of Research Findings (pp. 15-51). Research on Teaching and Learning in Higher Education. URL: https://www.research.ed.ac.uk/portal/files/14426330/ ENTWISTLE_Taking_Stock.pdf Weimer, M. (2002). Learner-centered teaching: Five key changes to practice. San Francisco, CA: Jossey-Bass. 
9. Guthrie, J. T. (2004). Classroom Contexts for Engaged Reading: An overview. In J.T. Guthrie,A. Wigfield, \& K. C.Perencevich(Eds.), Motivating Reading Comprehension: Concept-oriented Reading Instruction (pp. 1-24). Mahwah, NJ: Lawrence Erlbaum.

10. Gredler, M. (2009). Learning and Instruction Theory into Practice. New Jersey, NJ: Pearson.

11. Law, W. K. (2007). Frontiers for Learner-centered IS Education. Journal of Information Systems Education, 18(3), 313-320.

12. McDonald, F., Reynolds, J., Bixley,A., \& Spronken-Smith, R. (2017). Changes in Approaches to Learning over Three Years of University Undergraduate Study. Teaching \& Learning Inquiry, 5, 65-79. doi: https://doi.org/10.20343/teachlearninqu.5.2.6

13. Meece, J. L. (2003). Applying Learner-centered Principles to Middle School Education. Theory into Practice, 42(2), 109-116.

14. Norton, L. A. (2008). Action Research in Teaching and Learning: A Practical Guide to Conducting Pedagogical Research in Universities. Routledge: New York.

15. Panitz, T. (1996).Getting students ready for learning. Cooperative Learning and College Teaching, 6(2), 10-30.

16. Pathal, A., \& Intratat, C. (2012) Use of Semi-structured Interviews to Investigate Teacher Perceptions of Student Collaboration. Malaysian Journal of ELT Research, 8, 1-10.

17. Postareff, L., \& Lindblom-Ylänne, S. (2008). Variation in Teachers' Descriptions of Teaching: Broadening the Understanding of Teaching in Higher Education. Learning and Instruction, 18, 109-120. doi: https://doi.org/10.1016/j.learninstruc.2007.01.008

18. Postareff, L., Lindblom-Ylanne, S., \& Nevgi, A. (2007). The Effect of Pedagogical Training on Teaching in Higher Education. Teaching and Teacher Education, 23, 557-571. doi: https://doi.org/10.1016/j.tate.2006.11.01

19. Prosser, M., \& Trigwell, K. (1997). Relations between Perceptions of the Teaching Environment and Approaches to Teaching. British Journal of Educational Psychology, 67, 25-35. doi: https://doi.org/10.1111/j.2044-8279.1997.tb01224.x

20. Simon, B. (1999). Why no Pedagogy in England? In J. Leach \& B. Moon (Eds.), Learners and Pedagogy (pp. 34-45). London: Sage.

21. Singer, E., \& Couper, M. (2017). Some Methodological Uses of Responses to Open Questions and Other Verbatim Comments in Quantitative Surveys. Methods, Data, Analyses, 11, 20. doi: https://doi.org/10.12758/mda.2017.01

22. Stephenson, S., \& Troy, J. (2003). Higher Education Students' Attitudes to Student Centred Learning: Beyond "Educational Bulimia". Studies in Higher Education, 28, 321-334. doi: https://doi.org/10.1080/030750703092

23. Stoliarenko, O., Stoliarenko, O. (2014). Teaching the Culture of Tolerant Relationships to Students. Vinnytsia: Nilan-LTD.

24. Stoliarenko, O., Stoliarenko O. (2018). Valuable Attitude to a Person in the Theory and Practice of Education. Scientific Notes of Vinnitsa State Pedagogical University named after Mikhail Kotsyubynsky. Series Pedagogy and Psychology, 55, 38-42.

25. Trigwell, K., \& Prosser, M. (1996). Changing Approaches to Teaching: A Relational Perspective. Studies in Higher Education, 21, 275-284.

26. Weimer, M. (2002). Learner-centered Teaching: Five Key Changes to Practice. San Francisco, CA: Jossey-Bass. 